\title{
Green synthesis of the plant assisted nanoparticles from Euphorbia neriifolia L. and its application in the degradation of dyes from industrial waste
}

\author{
Shubhada S. Nayak ${ }^{1}$, Gurumeet C. Wadhawa ${ }^{1}$, K. B. Pathade ${ }^{2}$, Vitthal S. Shivankar ${ }^{3}$, \& Nitin A. \\ Mirgane ${ }^{*}$ \\ ${ }^{1}$ Rayat Shikshan Sansthas, Karmaveer Bhaurao Patil College, Vashi sector, 15 A Navi Mumbai, 400 703, Maharashtra, India \\ ${ }^{2}$ Maharaja Jivajirao Shinde Arts, Science, Commerce College, Shrigonda, Dist. Ahmednagar 413 701, Maharashtra, India \\ ${ }^{3}$ Rayat Shikshan Sansthas, Chhatrapati Shivaji College, Satara, Maharashtra, India \\ ${ }^{4}$ Department of Chemistry, SIES College of ASC, Sion (West), Mumbai 400 022, Maharashtra, India \\ *Email:mirgane@gmail.com
}

\section{ARTICLE HISTORY}

Received: 13 August 2020

Accepted: 01 November 2020

Published: 28 April 2021

KEYWORDS

Latex

Green synthesis

Industrial waste water

Dyes

Adsorption

\section{ABSTRACT}

In the world industries are growing very rapidly resulting in fast development. Various industries are coming up such as that of dyes, paints, pharmaceuticals etc. Dyes are used in various industries and release pollutants in the environment. It is necessary to remove such pollutants from the environment. Euphorbia neriifolia L. grow as the weed in the forests of the konkan region in waste land area. This weed is a typical latex bearing plant. This latex can be converted into the powder under sun drying process. This powder can be used for the preparation of Fe nanoparticles. The plant assisted synthesized nanoparticles have good particle size, morphology and band gap. These nanoparticles used for the degradation of the dye like Methylene Blue and Methylene Red from the industrial waste. It gives very good results. We can develop new catalyst for the degradation of the dyes from the industrial waste. It act as good catalyst by the simple non form of the catalyst. This catalyst is derived from the plant Euphorbia neriifolia L. latex.

\section{Introduction}

Industrial development occurs all over the world rapidly. This industrial development is possible with the use of lot of chemicals and different chemical products. As a result, a lot of the wastes are thrown out in the environment. This waste includes solid, liquid and many times gases (1). Most of the time solid and liquid wastes causes lot of pollution in water bodies. It became necessary to remove these toxic materials from water. The contemporary toxic removing techniques are costly. So, there is a need to develop cost (1-2) effective techniques such as adsorption, advanced biochemical treatment, photocatalysis etc. (2). Amongst these techniques photocatalyst is very common. Most of the time photocatalyst become inexpensive method for degradation of waste water (3). The photocatalyst are used due their band gap and activity. Use of application of nanoparticle depend upon on the size and band gap to overcome this (4). It became necessary to develop visible light or sunlight active photocatalyst, the most commonly used metal oxide photo catalyst such as Zinc oxide, Titanium dioxide, Ferrous oxide (5-6).

In this era, Nanotechnology is used in all the fields of science including healthcare to industry work (7-8). The nanoparticles are synthesized by various ways which involves, the use of hazardous chemicals. It is need of time to develop the environmentally friendly protocols with non-toxic by-products, mild reaction conditions, safety natural material as capping agent as part of the reducing agent (9-11). It has been observed that the nanomaterial prepared from the plant part as the capping agent are safer, best with good particle morphology and stable (12). Using plant material in

(C) Nayak et al (2021). This is an open-access article distributed under the terms of the Creative Commons Attribution License, which permits unrestricted use, distribution and reproduction in any medium, provided the original author and source are credited (https://creativecommons.org/licenses/by/4.0/)

To cite this article: Nayak S S, Wadhawa G C, Pathade K B, Shivankar V S, Mirgane N A. Green synthesis of the plant assisted nanoparticles from Euphorbia neriifolia L. and its application in the degradation of dyes from industrial waste. Plant Science Today. 2021;8(2):380-385. https://doi.org/10.14719/pst.2021.8.2.905 
the synthesis of the nanoparticles increase safety and decrease the pollution gives the eco-friendly way for the synthesis (13). Using plant material in synthesis of the biological nanomaterial gives rise to new branch known as nanobiotechnology (14). This study mainly deal with use of seeds, fruits, microbes, fungi, algae and other plant materials. This synthesized nanomaterial used in the medicine, pharma, plastic and other industry (15). These plant materials work as reducing agent and capping agent due to various neutral metabolites present in them (16). The nanomaterials are the use in field of biochemistry, environmental sciences, synthetic chemistry piezoelectric, catalytic piezoelectric, optoelectronics and semiconducting capacity (17). Most of metals used are Zinc, Ferrous, Cobalt, Manganese etc., th at have very good band-gap and binding energy. The plant assisted nanoparticles are used the various applications vapor-liquid-solid (VLS) (18), hydrothermal synthesis (19), vapor phase deposition (20), chemical vapor deposition (21), metallo-organic deposition of chemical vapors (22). The variety of the nanomaterial are synthesized, they have various shapes such as nanoparticle, nanorod, nanoparticles, nanoflowers (23).

These nanoparticles have potential applications in the removal of pollutants from environment, in production of active oxygen species, in hydrogen peroxide preparation (24), also used in the production of the solar cell or other materials (25). These nanoparticles used widely in the industry such as cosmetic industries, pharmaceutical, solar cell industries, bio-sensors, photo-catalysis (26). The large number of the plant material has been used such as Aloe vera (27), Calotropis gigantea (28), Citrus aurantifolia (29), Coriandrum sativum (30), Parthenium hysterophorus L. (31). the plant has the botanical classification the kingdom plantae, subkingdom Tracheobionta having division Magnoliophyta, subdivision Spermatophyte (32) Euphorbia neriifolia L. in plant belonging to the family Euphorbiaceae. $(33,34)$ This is the latex bearing family, contains the many active ingredients and used in many ayurvedic formulations like citrakadi taila, avittoladi bhasma, jatyadi varti, Snu highrta, abhaya lavana, jalodarariras, snuhidugdhadi varti used in various formulations vatavyadhi, gulma, udara sula, sotha, arsas (35) and the ayurvedic study (36) of India. This plant grows in India, Burma, Baluchistan mostly cultivated $(37,38)$. This type of plant secretes the latex. The plant is a large branched shrub occur in dry, rocky and hilly area. This is 3-5meter-tall, leaves are alternate, clustered around 2$3 \mathrm{~mm}$, over the area with the good developing the flowers and having good latex bearing property Female flowers rarely developed. In this research paper we have developed the simple plant assisted Fe nanoparticles from the latex of plant Euphorbia neriifolia L. this plant is very rare and it occur through the This plant Euphorbia neriifolia L. coated nanoparticles are used for the degradation of dyes. The mostly we are using dyes like Methylene blue and Methyl red dyes. This synthesized nanoparticle worked best photocatalyst for the degradation of the dyes.

\section{Materials and Methods}

Plant material was collected from the Dhutpapeshwar mandir with Latitude: $16^{\circ} 40^{\prime} 12.00^{\prime \prime}$ N, Longitude: $73^{\circ} 31^{\prime} 12.00^{\prime \prime} \mathrm{E}$ and identified by Dr. Arun Chandore Abasaheb Marathe Arts \& New Commerce Science College, Rajapur.

\section{Chemicals}

All chemicals were used of S.D. FINE and Loba companies. These chemicals used are highly pure and analytical grade and required further no purification.

\section{Characterization}

The UV Spectra of the synthesized nanoparticle characterized by the Shimadzu UV 1800. The IR Spectra was recorded by the Shimadzu IR infinity. The SEM was carried out by the Bruker D8 ADVANCE (Germany) diffractometer. TEM or the Transmission electron microscopy was carried using the Carbon coated grid FEI Technai G2 F20 instrument for such case ethanol was used as diluent. Scanning Electron Microscopy was studied using the Philips CM120 and LEO 1430VP instruments, X-ray diffraction was carried on Bruker D8 ADVANCE (Germany) diffractometer.

\section{Euphorbia neriifolia L. latex powder preparation}

Euphorbia neriifolia L. is the latex bearing plant, mostly maximum latex present in the plant in the morning time. The latex was collected in to the clean beaker using knife for making cut on the plant. This plant grows on the rocky region as weed. The latex collected in beaker then some amount of alcohol was added. This latex was dried with 1:3 amyl alcohol in light specially sun light and converted to the powder. This powder dried in oven at $30{ }^{\circ} \mathrm{C}-40{ }^{\circ} \mathrm{C}$ at above this temperature it get evaporated till constant weight was obtained. This latex contains various active biomaterial such as terpenes, flavonoids, alkaloids or other shikimates as the secondary metabolites. This was stored in the air tight container and kept in refrigerator at $20^{\circ} \mathrm{C}$.

\section{Green Synthesis of the FeNPs}

The green FeNPs (39) were produced taking $10 \mathrm{ml}$ of the iron precursor $\left(\mathrm{FeCl}_{3} \cdot 6 \mathrm{H}_{2} \mathrm{O}, 0.1 \mathrm{M}\right), 2 \mathrm{gm}$ of the plant Euphorbia neriifolia L. latex powder and $10 \mathrm{ml}$ of water and sonicated in special sonicator this reaction mixture for $2 \mathrm{hrs}$ at room temperature. Initially color was light brown after nanomaterial formation it changes to black indicating in this case the reduction of Fe ions to FeNPs. Then this material was subjected to the rotation for $3000 \mathrm{rpm}$ using special sonicator, supernatant liquid was collected kept in another beaker. Upper Liquid obtained was kept in the muffle furnace for $6 \mathrm{hrs}$ till constant weight was obtained, weight will change and decreases. The solution kept in desiccators to remove water and they are kept in the air tight container.

\section{Photo catalytic dye degradation using sun light (Methylene Blue dye)}

Photo catalytic dye degradation experiment was carried by modified procedure (40) in the $250 \mathrm{ml}$ conical flask. The $50 \mathrm{ml}$ of Methylene Blue (MB) dye solution prepared by taking $10 \mathrm{mg}$ of MB dye per litre 
was added to $250 \mathrm{ml}$ conical flask. The $25 \mathrm{mg}$ of our biocatalyst was added to it. The suspension formed stirred in the sunlight. This can be done by keeping this under stirring for the given time interval at every 30 min. UV spectra was recorded using the UV Spectrophotometer Shimadzu 1800. All samples from the industrial dye degradation carried out is reported in Table 1-3.

\section{Results and Discussion}

\section{UV-Vis data analysis of FeNP using Euphorbia neriifolia L. Latex Powder}

Reduction of iron using plant Euphorbia neriifolia L. latex powder was studied using making reaction solution by measuring the UV absorption. This can be done using Shimadzu UV 1800 from wavelength 200$600 \mathrm{~nm}$. The maximum absorption was observed at $370 \mathrm{~nm}$, indicate the formation of the nanoparticles (Fig. 1).

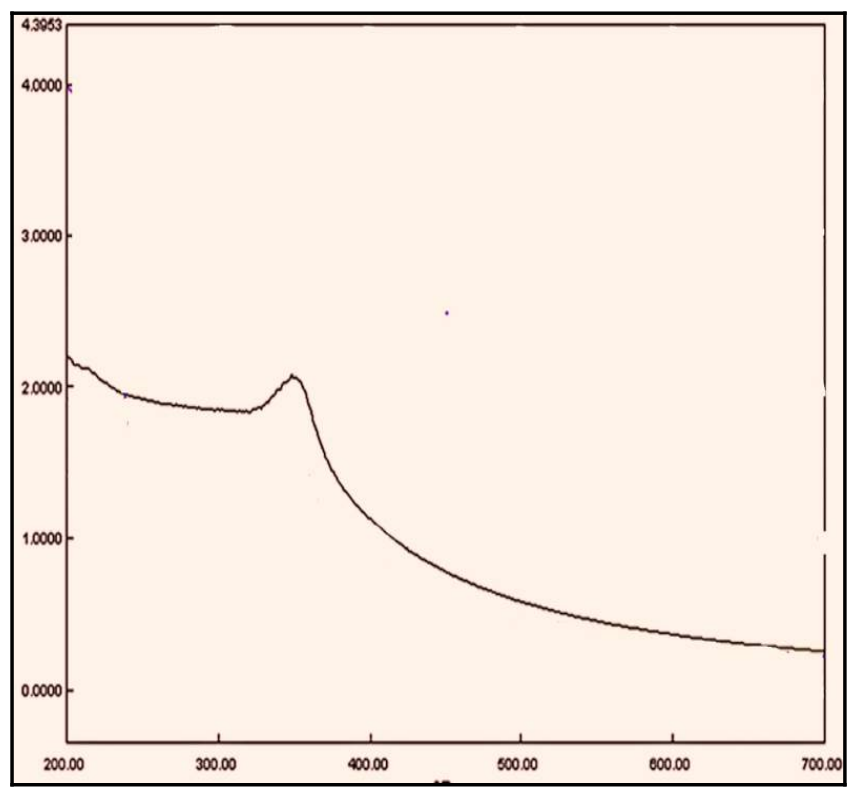

Fig. 1. UV Spectra obtained shows that FeNP coated with biomaterial.

\section{Fourier Transform-Infrared data analysis of FeNPs}

FTIR spectroscopy was used to identify the functional groups. We have scanned at $500-4000 \mathrm{~cm}^{-1}$. The peak got at $3400-3500 \mathrm{~cm}^{-1}$ shows for the $-\mathrm{OH}$ group, 2900$300 \mathrm{~cm}^{-1}$ band for $\mathrm{C}-\mathrm{H}$ Stretching, while certain band at $1600-1800 \mathrm{~cm}^{-1}$ show the $\mathrm{C}=\mathrm{C}$ and $\mathrm{C}=\mathrm{O}$ stretching at 600 to $700 \mathrm{~cm}^{-1}$ for the iron and oxygen bond (Fig. 2).

\section{$X$-ray diffraction data analysis of FeNPs}

Plant Euphorbia neriifolia L. latex powder was used for the preparation used for the coating of FeNPs. The FeNPs particles was confirmed using the XRD (Fig. 3). The structural composition of the synthesized nanoparticles from the plant Euphorbia neriifolia L. The nanoparticles formed by using the XRD analysis Fig. 3 shows the formation of nanoparticles using the angle and planes 2theta values of $20.2^{\circ}, 34.5^{\circ}, 37.2^{\circ}$, $40.91^{\circ}, 48.8^{\circ}, 56.3^{\circ}$ and $64.21^{\circ}, 70.21$.

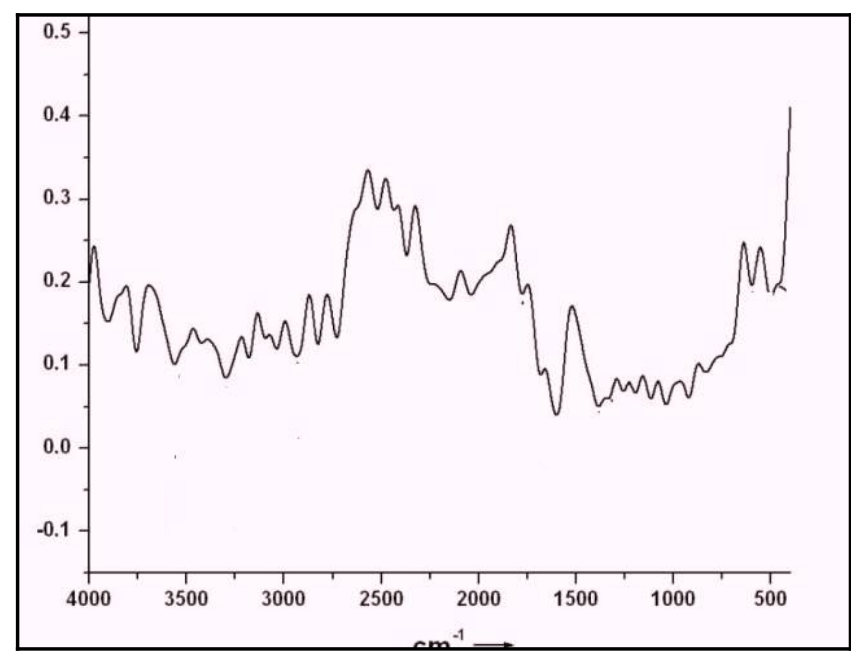

Fig. 2. FTIR Spectrum indicate the formation of the Fe nanoparticles. $\mathrm{x}$ axis $\mathrm{Cm}^{-1}$ (Frequency) and $\mathrm{Y}$ axis transmittance.

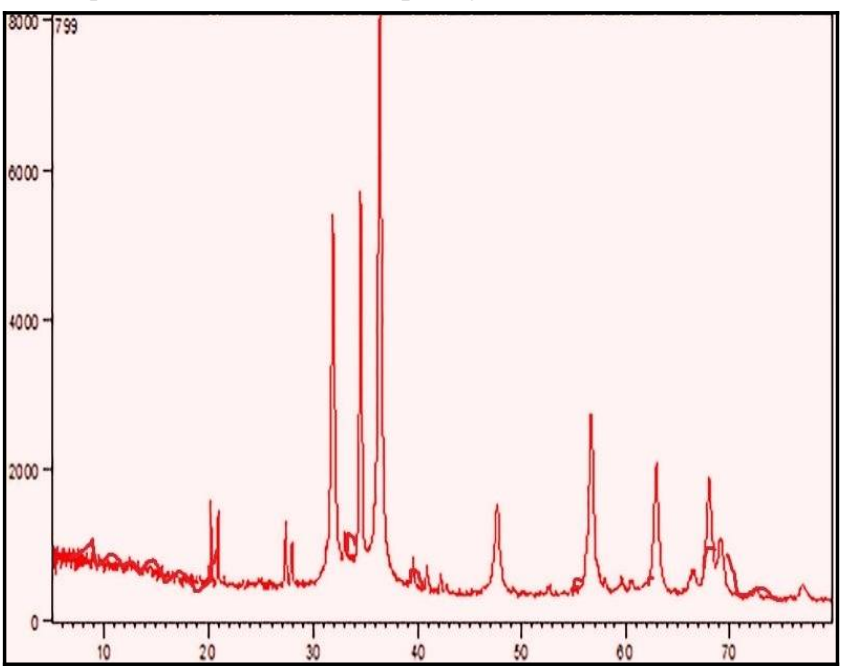

Fig. 3. X-ray diffraction

$\mathrm{x}$ axis as angle diffraction and $\mathrm{y}$ axis intensity.

\section{Scanning electron microscopy}

Euphorbia neriifolia L. latex powder was used for the preparation used for the coating of FeNPs. The FeNPs nanoparticles was confirmed using the SEM (Fig. 4). The data analysis of FeNPs got by plant Euphorbia

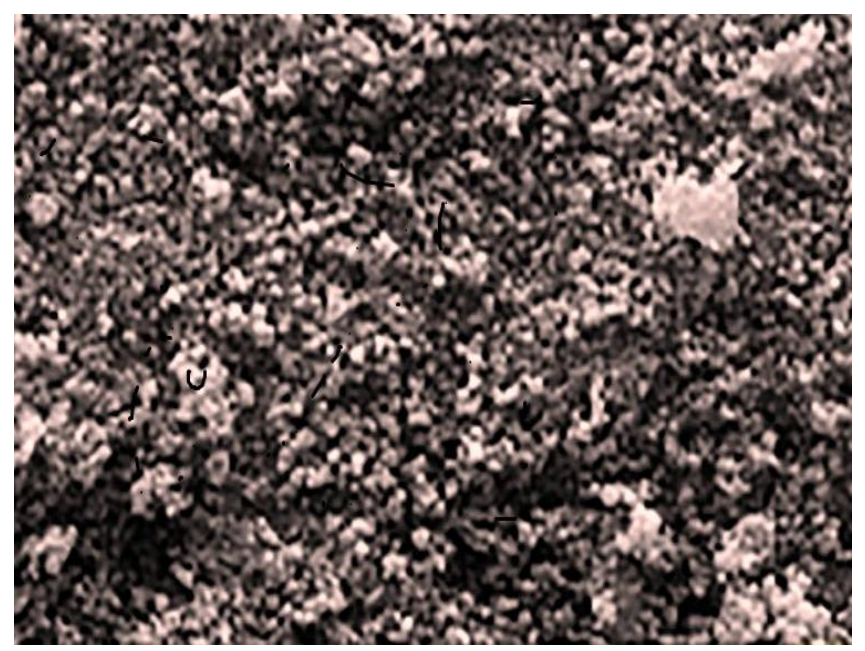

Fig. 4. Scanning electron microscopy. 
neriifolia L. latex powder studied using the scanning electron microscopy (SEM). The SEM result show that the bio-nanoparticle was prepared having very good particle size around 40-50 $\mathrm{nm}$.

\section{Transmission electron microscopy}

TEM was used to determine the shape and size of the nanoparticles. The TEM Spectra (Fig. 5) show that the nanoparticle formed with good shape and size. They have size around 40-50 nanometer. Photocatalytic

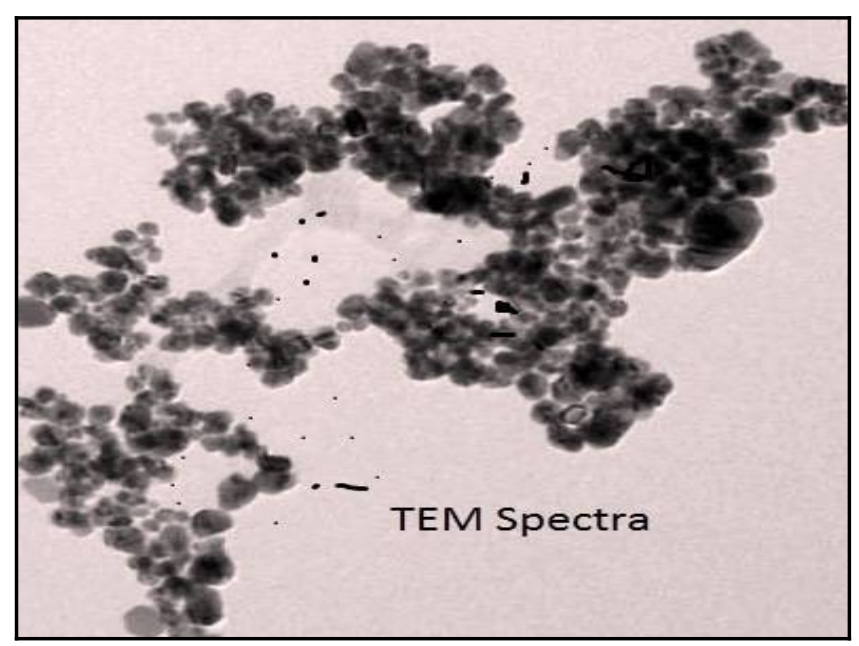

Fig. 5. Transmission electron microscopy spectra.

dye degradation using sun light (Methylene Blue). The photocatalytic methylene blue dye degradation using sun light studied carried out by measuring absorption with time. The results obtained are tabulated in Table 1. From the graph (Fig. 6), we have observed that dye degradation takes place as time proceed methylene blue dye gets degraded in the

Table 1. Time and absorption obtained for MB dye.

\begin{tabular}{rrrr}
\hline Time & Absorption & Time in min & Absorption innm \\
\hline 0 & 690 & 390 & 540 \\
\hline 30 & 685 & 450 & 530 \\
\hline 60 & 680 & 480 & 525 \\
\hline 90 & 675 & 510 & 510 \\
\hline 120 & 670 & 540 & 490 \\
\hline 150 & 650 & 570 & 480 \\
\hline 180 & 640 & 600 & 470 \\
\hline 210 & 630 & 630 & 460 \\
\hline 240 & 620 & 660 & 450 \\
\hline 270 & 600 & 690 & 445 \\
\hline 300 & 590 & 720 & 430 \\
\hline 330 & 565 & 750 & 420 \\
\hline 360 & 550 & 780 & 400 \\
\hline
\end{tabular}

sunlight. Photocatalytic dye degradation using sun light (Methyl Red).

Similar experiment was carried out with Methyl Red (MR) by taking the same quantity. The results obtained are tabulated in Table 2. From above the graph (Fig. 7), it has been observed that the degradation of the MR takes place into simpler chemical with moderate rate photo catalytic dye degradation using sun light of various dye industry.

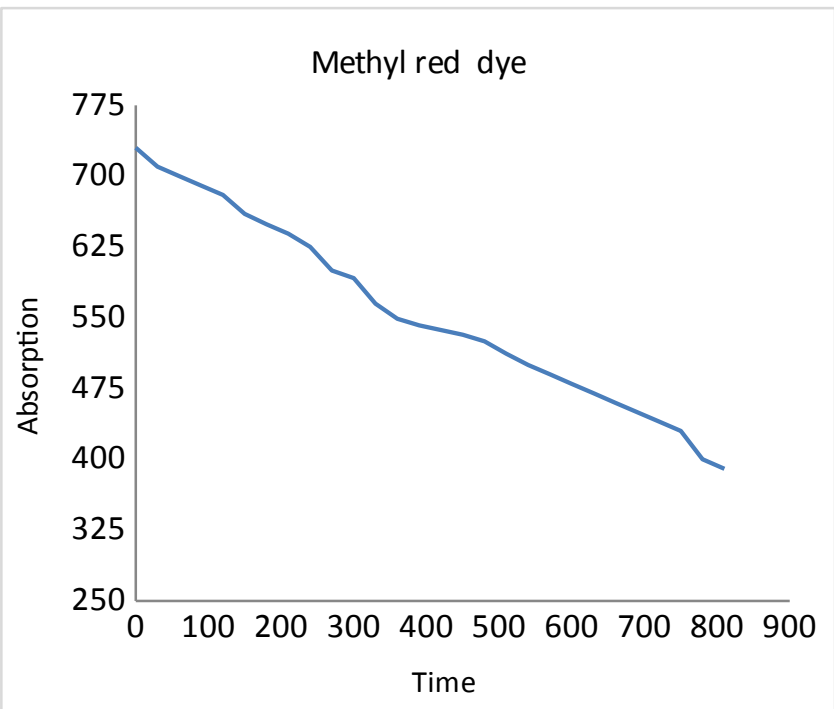

Fig. 6. Time in Min Vs absorption for Methylene Blue dye.

Table 2. Time and absorption obtained for MR dye.

\begin{tabular}{rrrr}
\hline Time & Absorption & Time min & $\begin{array}{c}\text { Absorption } \\
\text { in nm }\end{array}$ \\
\hline 0 & 730 & 450 & 532 \\
\hline 30 & 710 & 480 & 525 \\
\hline 60 & 700 & 510 & 512 \\
\hline 90 & 690 & 540 & 500 \\
\hline 120 & 680 & 570 & 490 \\
\hline 150 & 660 & 600 & 480 \\
\hline 180 & 649 & 630 & 470 \\
\hline 210 & 639 & 660 & 460 \\
\hline 240 & 625 & 690 & 450 \\
\hline 270 & 600 & 720 & 440 \\
\hline 300 & 592 & 750 & 430 \\
\hline 330 & 565 & 780 & 400 \\
\hline 360 & 549 & 810 & 390 \\
\hline 390 & 542 & - & - \\
\hline & & &
\end{tabular}

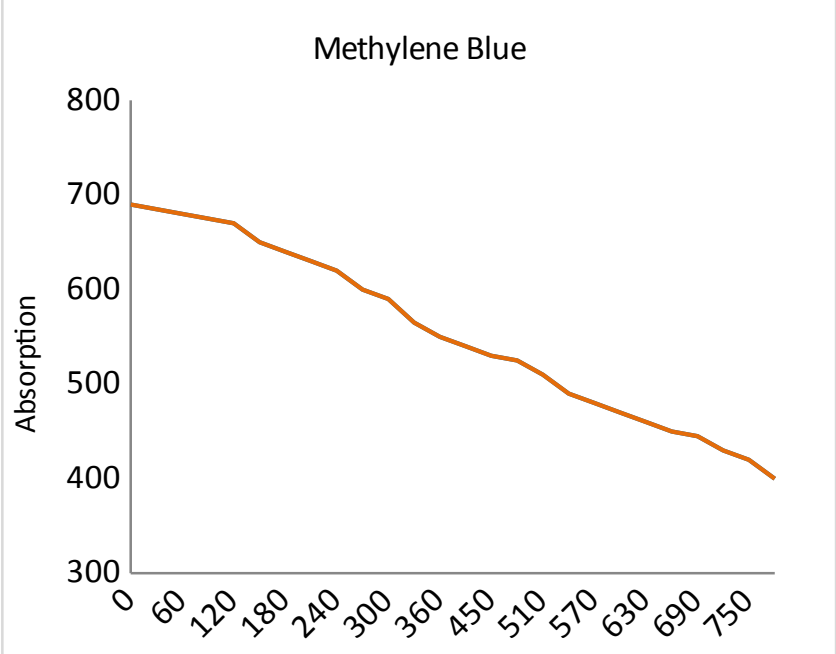

Fig. 7. Time in Min Vs absorption for MR dye.

The photocatalytic dye degradation of various dye industries studied using sun light. The results obtained are tabulated in Table 3. From the graph (Fig. 8), it has been observed that as we increase the time of exposure to sunlight the degradation takes place and dye get degraded to simple chemicals. 
Table 3. Photocatalytic dye degradation of various dye industry Time Vs absorption.

\begin{tabular}{|c|c|c|c|c|}
\hline Time & Industry I & Industry II & Industry III & Industry IV \\
\hline 0 & 780 & 760 & 800 & 770 \\
\hline 30 & 770 & 750 & 790 & 740 \\
\hline 60 & 760 & 740 & 780 & 730 \\
\hline 90 & 750 & 730 & 770 & 710 \\
\hline 120 & 740 & 720 & 760 & 690 \\
\hline 150 & 730 & 710 & 750 & 670 \\
\hline 180 & 700 & 700 & 740 & 650 \\
\hline 210 & 690 & 690 & 730 & 635 \\
\hline 240 & 670 & 680 & 720 & 620 \\
\hline 270 & 660 & 670 & 710 & 605 \\
\hline 300 & 654 & 660 & 700 & 595 \\
\hline 330 & 645 & 650 & 685 & 580 \\
\hline 360 & 630 & 630 & 670 & 565 \\
\hline 390 & 610 & 610 & 660 & 550 \\
\hline 450 & 590 & 590 & 640 & 545 \\
\hline 480 & 576 & 570 & 620 & 530 \\
\hline 510 & 560 & 560 & 600 & 514 \\
\hline 540 & 540 & 550 & 585 & 500 \\
\hline 570 & 520 & 540 & 570 & 485 \\
\hline 600 & 500 & 510 & 560 & 400 \\
\hline 630 & 490 & 490 & 540 & 385 \\
\hline 660 & 480 & 470 & 525 & 370 \\
\hline 690 & 470 & 460 & 500 & 360 \\
\hline 720 & 460 & 450 & 485 & - \\
\hline 750 & 430 & 420 & 470 & - \\
\hline 780 & 410 & 400 & 450 & - \\
\hline 810 & 400 & 380 & 430 & - \\
\hline 840 & 390 & 350 & 420 & - \\
\hline
\end{tabular}

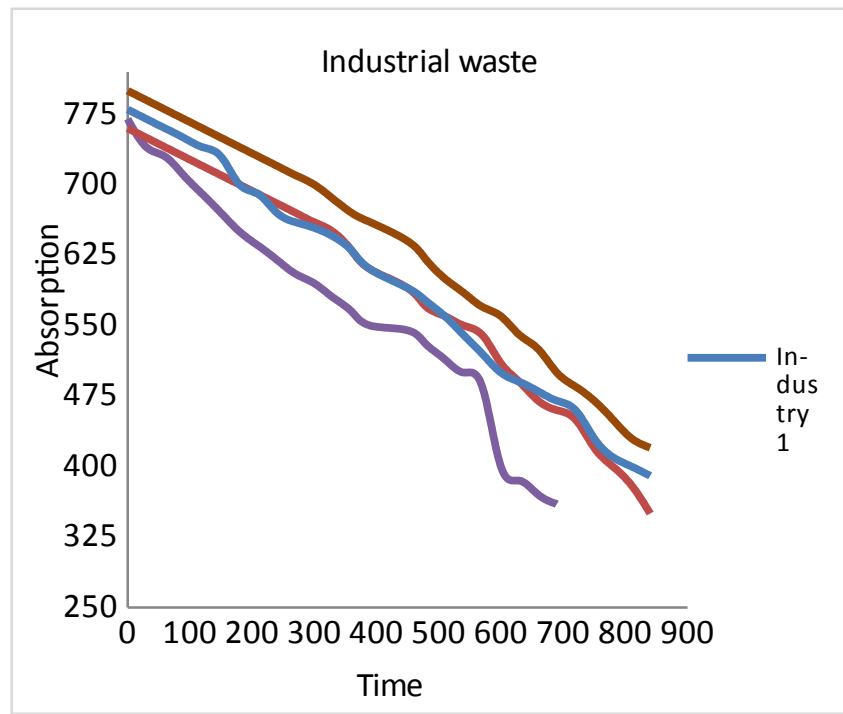

Fig. 8. Time and absorption obtained for various industry.

\section{Conclusion}

FeNP using plant Euphorbia neriifolia L. latex powder were successfully synthesized and characterized by XRD, IR, SEM, EDX and TEM. These synthesized nanomaterials were successfully applied for the degradation of both dyes. It gives very good degradation of the MB and MR under solar irradiation. These are successfully applied to the various dye industries. We have studied waste of four dye industries. This catalyst is reusable and green. This coating plant Euphorbia neriifolia L. material was waste latex used as capping and reducing agent, this may be useful for the industrial application.

\section{Acknowledgements}

Authors are thankful to Principal, Rayat Shikshan sansthas Karmaveer Bhaurao Patil College, Vashi, Navi Mumbai for providing the necessary support. We are also thankful to Raya Shikshan Sanstha Satara, for their Support. No funding had been received from any agency.

\section{Authors' contributions}

Concept and work plan were supervised by SN and GW. All the analytical experiment was performed by $\mathrm{KP}$, SN and GW. The manuscript writing and statistical calculation were done by GW. Necessary and final correction done by NM and VS. All authors read and approved the final manuscript.

\section{Conflict of interests}

Authors do not have any conflict of interests to declare.

\section{References}

1. Ameta SC. Advanced oxidation processes for waste water treatment. Emerging Green Chemical Technology. 2018 Feb 23;1-12. https://doi.org/10.1016/B978-0-12-810499-6.00001-2

2. Glaze WH, Kang JW, Chapin DH. The chemistry of water treatment processes ionvolving ozone, hydrogen peroxide and ultraviolet radiation. ozone: Science \& Engineering. 1987;9:335-52. http://dx.doi.org/10.1080/01919518708552148

3. Ku Y, Leu RM, Lee KC. Decomposition of 2-chlorophenol in aqueous solution by UV irradiation with the presence of titanium dioxide. Water Res. 1996;30:2569-78. https://doi.org/10.1016/S0043-1354(96)00147-9

4. Zhang F, Wang X, Liu H, Liu C, Wan Y, Long Y, Cai Z. Recent advances and applications of semiconductor photocatalytic technology. Appl Sci. 2019;9(12):2489(1-13).

5. Chakrabarti S, Dutta BK. Photocatalytic Degradation of Model Textile Dyes in Wastewater Using ZnO as Semiconductor Catalyst. J Hazard Mater. 2004;112 (112):269-78.

6. Fujishma A, Zhang X. Titanium dioxide photocatalysis: present situation and future approaches. Comptes Rendus Chimie. 2006;9(5-6):750-60.

7. Mazzola L. Commercializing nanotechnology. Nat Biotechnol. 2003; 21:1137-43. https://doi.org/10.1038/nbt1003-1137

8. Wali M, Khan MA, Nazir M, Siddiquah A, Mushtaq S, Hashmi SS, Abbasi BH. Papaver Somniferum L. mediated novel bioinspired Lead Oxide (Pbo) and Iron Oxide $\left(\mathrm{Fe}_{2} \mathrm{O}_{3}\right)$ nanoparticles: In-vitro biological applications, biocompatibility and their potential towards HEPG2 cell line. Materials Science and Engineering: C. 2019;103:109740. https:// doi.org/10.1016/j.msec.2019.109740

9. Thakkar KN, Mhatre SS, Parikh RY. Biological synthesis of metallic nanoparticles. Nanomedicine. 2010;6:257-62. PMID: 19616126. https://doi.org/10.1016/j.nano.2009.07.002

10. Mirgane NA, Shivankar VS, Kotwal SB et al. Waste pericarp of Ananas comosus in green synthesis zinc oxide nanoparticles and their application in waste water treatment. Materials Today: $\quad$ Proceedings. $\quad 2020 \quad$ July 9. https://doi.org/10.1016/j.matpr.2020.06.045 
11. Mirgane NA, Shivankar VS, Kotwal SB et al. Degradation of dyes using biologically synthesized zinc oxide nanoparticles. Materials Today: Proceedings. 2020 July 9 https://doi.org/10.1016/j.matpr.2020.06.037

12. Kulkarni N, Muddapur U. Biosynthesis of metal nanoparticles: A review. J Nanotech. 2014; 2014:510246. https://doi.org/10.1155/2014/510246

13. Abdel-Hameed ESS. Total phenolic contents and free radical scavenging activity of certain Egyptian Ficus species leaf samples. Food Chemistry. 2009;114(4):1271-77. https://doi.org/10.1016/j.foodchem.2008.11.005

14. Manuela S, Adriana P, Toloman D, Adriana D, Lung I, Katona G. Enhanced photocatalytic degradation properties of Zinc Oxide nanoparticles synthesized by using plant extracts. Materials Science in Semiconductor Processing. 2015;39:23-29. https://doi.org/10.1016/j.mssp.2015.04.038

15. Mittal AK, Chisti, Y, Banerjee YC. Synthesis of metallic nanoparticles using plant extracts. Biotechnol Adv. 2013;31(2):346-56.

https://doi.org/10.1016/j.biotechadv.2013.01.003

16. Sangeetha G, Rajeshwari S, Venckatesh R. Green synthesis of Zinc Oxide nanoparticles by Aloe barbadensis Miller leaf extract: Structure and optical properties. Mater Res Bull. 2011;46(12):2560-66

https://doi.org/10.1016/j.materresbull.2011.07.046

17. Sharma D, Sharma S, Kaith BS, Rajput J, Kaur M. Synthesis of ZnO nanoparticles using surfactant free in-air and microwave method. Appl Surf Sci. 2011;257(22):9661-72. https://doi.org/10.1016/j.apsusc.2011.06.094

18. Chen $\mathrm{CH}$, Chang SJ, Chang SP, et al. Fabrication of a white-lightemitting diode by doping gallium into $\mathrm{ZnO}$ nanowire on a $\mathrm{P}$ gan substrate. J Phys Chem. C. 2010;114:12422-26. https://doi.org/10.1021/jp101392g

19. Hsu CL, Chen KC. Improving piezoelectric nanogenerator comprises $\mathrm{ZnO}$ nanowires by bending the flexible pet substrate at low vibration frequency. J Phys Chem. C. 2012;116(16):935155. https://doi.org/10.1021/jp301527y

20. Gao PX, Ding Y, Wang ZL. Crystallographic orientation-aligned ZnO nanorods grown by a tin catalyst. Nano Lett. 2003;3:131520. https://doi.org/10.1021/nl034548q

21. Hu Y, Zhang Y, Chang Y, Snyder RL, Wang ZL. Optimizing the power output of a ZnO photocell by piezopotential. ACS Nano. 2010; 4(7):4220-24. https://doi.org/10.1021/nn1010045

22. Yang JL, An SJ, Park WI, Yi GC, Choi W. Photocatalysis using ZnO thin films and nanoneedles grown by metal-organic chemical vapor deposition. Adv Mater. 2004;16(18):1661-64. https://doi.org/10.1002/adma.200306673

23. Meulenkamp EA. Synthesis and growth of ZnO nanoparticles. J Phys Chem. https://doi.org/10.1021/jp980730h 1998:102(29):5566-72.

24. Khan M, Al-Marri AH, Khan, M. et al. Green Approach for the Effective Reduction of Graphene Oxide Using Salvadora persica L. Root (Miswak) Extract. Nanoscale Res Lett. 2015;10:281. https://doi.org/10.1186/s11671-015-0987-z

25. Saitoh L, Babu RR, Kannappan S, Kojima K, Mizutani T, Ochiai S. Performance of spray deposited poly (N-9"-hepta-decanyl2,7-carbazole-alt-5,5-(40, 70-di-2-thienyl-20,10, 30 benzothiadiazole))(6,6)-phenyl-C61-butyric acid methyl ester blend active layer based bulk heterojunction organic solar cell devices. Thin Solid Films. 2012;520(7):3111-17.
26. Wang ZL. Zinc oxide nanostructures: Growth, properties and applications. J Phys Cond Matt. 2004;16(25):R829. https://doi.org/10.1088/0953-8984/16/25/R01

27. Ali K, Dwivedi S, Azam A, Saquib Q, Al-Said MS, Alkhedhairy AA, Musarrat J. Aloe vera extract functionalized zinc oxide nanoparticles as nanoantibiotics against multi-drug resistant clinical bacterial isolates. J Colloid Interface Sci. 2016;15:14556. https://doi.org/10.1016/j.jcis.2016.03.021

28. Gnanasangeetha D, Sarala Thambavani D. One pot synthesis of zinc oxide nanoparticles via chemical and green method. Res J Mater Sci. 2013:1:1-8. http://www.isca.in/MATERIAL_SCI/Archive/v1/i7/1.ISCARJMatS-2013-023.pdf

29. Samat NA, Nor RM. Sol-gel synthesis of zinc oxide nanoparticles using Citrus aurantifolia extracts. Ceram Int 2013;39:S545-S548.

https://doi.org/10.1016/j.ceramint.2012.10.132

30. Singh RP, Shukla VK, Yadav RS, Sharma PK, Singh PK, Pandey AC. Biological approach of zinc oxide nanoparticles formation and its characterization. Adv Mater Lett. 2011;2(4)313-17. http://dx.doi.org/110.5185/amlett.indias.204

31. Rajiv P, Rajeshwari S, Venckatesh R. Bio-fabrication of zinc oxide nanoparticles using leaf extract of Parthenium hysterophorus L. and its size-dependent antifungal activity against plant fungal pathogens. Spectrochim. Acta A Mol Biomol $\quad$ Spectrosc. 2013;112:384-87. https://doi.org/10.1016/j.saa.2013.04.072

32. Anonymous. Global information hub on integrated medicine (Globinmed). (Online). Kaula-Lampur: Herbal Medicine Research Centre, Institute of Medical Research. Available from Anonymous The plant list, version 1.1. 2013.

33. Kirtikar KR, Basu BD. (2nd ed.), Indian Medicinal Plants, vol III, Lalit Mohan Basu, Allahabad. 2006:2201-04.

34. Webster G. Classification of the Euphorbiaceae. Ann Mo Bot Gard. 1994;81:03-32.

35. Chunekar KC. (2nd ed.) Illustrated DravyagunaVijnana, vol. II, ChaukhambhOrientalia, Varanasi, 2005:924-25.

36. Controller of Publications, Ministry of Health and Family Welfare, Department of Indian Systems of Medicine and Homoeopathy, Government of India (1st ed.), The Ayurvedic Pharmacopoeia of India. Part-I, vol. I, National Institute of Science Communication (CSIR), New Delhi. 2001:100. https://doi.org/10.1016/j.crci.2005.02.055

37. Anonymous. The Wealth of India, a dictionary of Indian raw materials and industrial products (Raw materials), Vol. III (DE), Central Institute of Medicinal and Aromatic Plants, New Delhi. 2003:226-28. $\quad$ PMID: 15302448 https://doi.org/10.1016/j.jhazmat.2004.05.013

38. Ved DK, Sureshchandra ST, Barve V, Srinivas V, Sangeetha S, Ravikumar K et al. Plant details. FRLHT's ENVIS Centre on Medicinal Plants, Bengaluru. 2016.

39. Manquián-Cerda K, Cruces E, Angélica Rubio M, Reyes C, Arancibia-Miranda N. Preparation of nanoscale iron (oxide, oxyhydroxides and zero-valent) particles derived from blueberries: Reactivity, characterization and removal mechanism of arsenate. Ecotoxicology and Environmental Safety.

2017;145:69-77. https://doi.org/10.1016/j.ecoenv.2017.07.004

40. Jayakumar G, Albert Irudayaraj A, Dhayal Raj A. Photocatalytic Degradation of Methylene Blue by Nickel Oxide Nanoparticles. Materials Today: Proceedings. 201711 Nov.; 4(11):11690-95. 